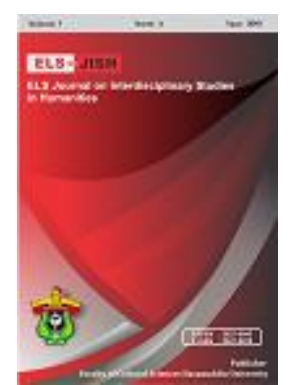

ELS-JISH

ELS Journal on Interdisciplinary Studies on Humanities

Volume 2 Issue 4, 2019

ISSN (print) : 2621-0843

ISSN (online) : 2621-0835

Homepage : http://journal.unhas.ac.id/index.php/jish

\title{
Students' Perceptions towards Using Mobile Application in Learning Speaking
}

\author{
Desika Rinanda ${ }^{1}$, Suparno ${ }^{2}$, Sri Samiati Tarjana ${ }^{3}$ \\ 1'desikarinanda@gmail.com
}

\begin{abstract}
The dramatic advancement technologies, particularly mobile applications, have influenced the education sector. The integration of mobile applications in education to change the teaching-learning process has taken place and led to innovative learning, including English language learning. Hence, this study aimed to find out the students' perceptions and the factors influencing students' perceptions toward the use of mobile application in learning English particularly speaking. To reach the objectives, this study used case study as the research method. The data were collected mainly through interview and observation. The participants were five vocational school students in Surakarta, Central Java, Indonesia. They were purposively selected because they had been familiar with mobile application and they had been taught speaking English using mobile application by their teacher, so that they could give adequate information. The research findings showed positive perception from the students toward the use of Learn English Conversation application in learning speaking. They declared that the use of Learn English Conversation application could facilitate them in practicing speaking, bring fun and enjoyable learning during the learning process. Moreover, their positive perceptions were influenced by several factors such as the flexibility and the new learning experience given by the mobile application, the ease to run the mobile application and unrequired a lot of internet quota when the students run the mobile application.
\end{abstract}

Keywords: Students' Perceptions, Mobile Application, Speaking Learning

How to cite: Rinanda, D., Suparno, Tarjana, S. S. (2019). Students' Perceptions towards Using

Mobile Application in Learning Speaking. ELS Journal on Interdisciplinary Studies in Humanities, 2 (4), 499-514

\section{Introduction}

Currently, mobile devices, portable devices, and internet access such as smartphones or tablets have become a part of human's modern daily life. Those are used for various activities, including educational and learning activities. According to West and Vosloo (2013) in Howlett \& Waemusa (2019), mobile devices provide students the flexibility to follow their interests and move at their own pace, which can increase their motivation to pursue learning opportunities. Moreover, the use of mobile devices in language learning process is called mobile-assisted language learning (MALL). Mobile-assisted language learning (MALL) differs from computerassisted language learning in its use of personal, portable devices that enable new

\footnotetext{
${ }^{1,2,3}$ Universitas Sebelas Maret, Indonesia 
ways of learning emphasizing continuity or spontaneity of access and interaction across different contexts of use (Kukulska-hulme, Agnes, \& Shield, 2008). Furthermore, Kukulska-hulme \& Agnes (2012) state that the anytime, anywhere learning slogan in MALL has been very prosperous and keeps on inspire in the 21st century. This flexibility in location and time of learning motivates the learners to practice the EFL activities. Mobile-assisted language learning (MALL) can also facilitate learning across both formal and informal. Comas-Quinn, Mardominggo, Raquel, \& Valentine (2009) claim that integrating the application of mobile technologies to learning can promote the active participation of learners, provide diverse formal and informal learning contexts, facilitate situated learning, and support a learning community.

Smartphones are, by far, the most popular Mobile-Assisted Language Learning (MALL) (Ekinci \& Ekinci, 2017) and the majority of MALL activities indeed seem to make use of mobile phones as mobile devices (Kukulska-hulme et al., 2008; Mehta, 2012). The smartphones turn into an education tool thanks to mobile applications. Mobile application or mobile apps is a software that is designed and intended to run on mobile devices such as smartphones, tablets, and PDAs (Liu \& He, 2014). With the help of mobile applications, English language learning enters a new era. The use of the mobile application to facilitate learning English can decrease the boredom, which usually arises from the traditional ways of teaching, as well as the time and places limitations. Additionally, West \& Vosloo (2013) in Howlett \& Waemusa (2019), state that MALL, including mobile application, can bridge formal and informal learning. It affords students the ability to easily access supplementary materials to clarify ideas introduced by a teacher in learning English.

Today, smartphone users can choose and download various free mobile applications in application stores such as App Store (iOS smartphone) and Playstore (Android smartphone). Among a great variety of iOS and Android apps, there is a considerable number of apps facilitating second/foreign language learning (Godwinjones, 2011). Moreover, a large number of mobile applications have been designed for English speaking learning. It is mentioned that in the EFL context, speaking has been considered as the most challenging skill for students, and it is unable to offer enough opportunities for speaking practice (Ahn \& Lee, 2016). Several studies even noted that EFL students face numerous problems in learning English speaking. A study conducted by Coskun (2016), finds that Turkish EFL students cannot speak English fluently because of some factors such as lack of experience abroad, limited speaking practice opportunities outside the classroom, feeling anxious while speaking and the course book which does not include colloquial English. It is in line with a study by Al-sobhi \& Preece (2018) that mention that most Arab students find difficulty in communicating freely in English due to certain factors such as students' limited knowledge of English language, lack of confidence and motivation. Additionally, Hamad, Metwally, \& Alfaruque (2019) state that body language, the right pronunciation of English letters, intonation, confidence, and correct usage of vocabulary is always a problem that is faced by both teachers and learners. Meanwhile, Machmud \& Abdulah (2018) state that one problem that often appears in EFL instructions in Indonesian Schools, especially teaching a speaking skill, is the limited time allocation. In only 80 minutes, teachers must be able to use it to teach four language skills (reading, writing, listening, and speaking) at once so that it is almost impossible to cover all students to do the practice, mainly practice their 
English speaking. For those reasons, the emergence of mobile application in smartphones related to English speaking learning provides students the facility to improve their desire in learning English speaking. Moreover, with the presence and flexibility of mobile apps, it allows the students to have more time to practice their speaking. They can practice their English speaking not only in the classroom but also outside of the classroom. Besides, (González, 2012) emphasizes that using mobile apps for learning speaking also has excellent potential to practice and improve certain aspects of English pronunciation, such as individual phonemes, stress, and intonation.

From hundreds of speaking applications on the application store, Learn English Conversation is a downloadable application that can use to facilitate students in learning speaking. Learn English Conversation application offers many activities for practicing English speaking, and it is available for free for smartphones. The features on these applications are designed for practicing pronunciations, practicing intonation, accent, expression within an appropriate situation, and even vocabulary learning. One of the features in Learn English Conversation application also offers to connect to people who are learning English so that they can practice their English together. This apps also provides game features to make speaking learning more fun and motivates them.
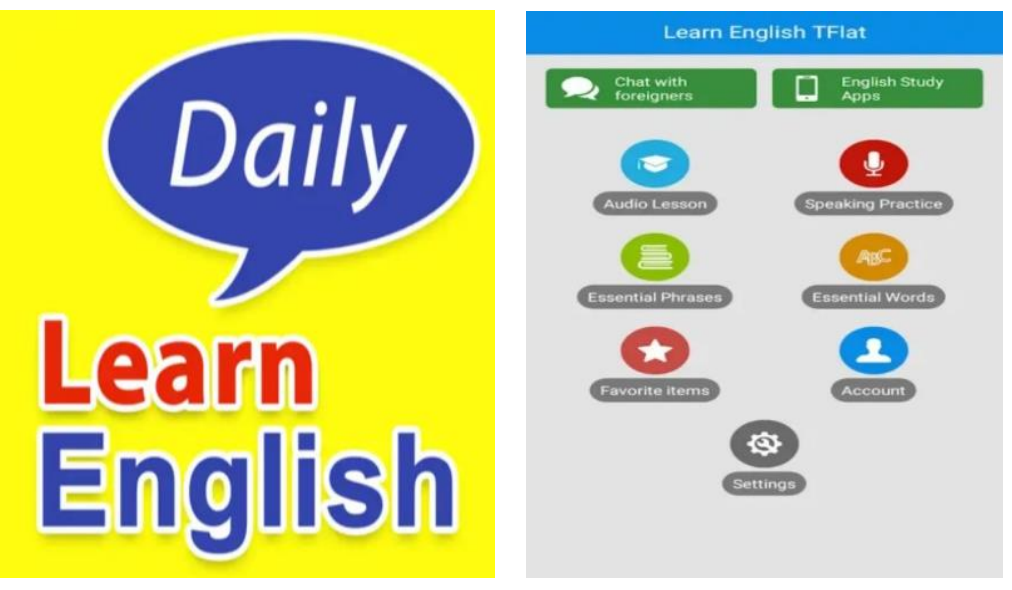

Figure 1. Learn English Conversation Application

This present study, on the other hand, is considered different from some previous relevant researches. A previous study by Guo (2015), focuses on investigating the relevant learning theories underpinning the current mobile apps for English speaking learning. Moreover, a study conducted by Han \& Keskin (2016) investigates the use of the mobile application to reduce EFL speaking anxiety. The results revealed that mobile application experiences significantly impacted the students' language acquisition by lowering EFL speaking anxiety. Besides, the previous study by Hamad et al. (2019) investigates the impact of using Youtube and audio tracks imitation on improving speaking skills of EFL learners. The results revealed that using Youtube and audio tracks imitation has a positive impact on the effectiveness of the speaking skills, fluency, and pronunciation of EFL learners. Most of those previous study investigating the use of mobile devices in English language instructions only look at from the language professionals and researchers' 
perspectives and researchers. There are not many studies revealing the students' perception of using mobile technology, particularly on the use of mobile apps in speaking learning. However, the students' input regarding how they perceive mobile application in their speaking learning process seems to be valued and is to be considered essential for the implementation of any instructional intervention. Therefore, considering those facts, this study focuses on investigating the students' perception of the use of the mobile application in learning English speaking, and this study attempts to attentions on Learn English Conversation application as the mobile applications used in English speaking learning in this study. In order to find out the students' perceptions, the research questions are formulated as follow:

1. What are the students' perceptions toward using Learn English Conversation application in learning to speak English?

2. What are the factors that influence students' perceptions toward using Learn English Conversation application in learning to speak English?

\section{Method}

This study is qualitative research which used case study method as a research design. Case study method is research method that tends to explore in depth information about the activity or phenomenon. The participants were five students from one of the vocational schools in Surakarta, Central Java, Indonesia and they were purposively selected. The rationale of choosing those participants was because all participants had been familiar with mobile application and they had been taught speaking English using mobile application, particularly Learn English Conversation application by their teacher.

The interviews and observations were carried out by the researchers at the school in order to get the information needed which deals with the students' perceptions toward using Learn English Conversation application in learning speaking. In-depth interviews were done and digitally recorded and transcribed. The interviews are designed as primary data to obtain students' perceptions toward the use of Learn English Conversation mobile application and the factor influenced their perception. Then, after interviewing the participants, the researchers observed the learning activities in the classroom to clarify what the students stated in the interview process. (Robson, 2002) claims that what people do may differ from what they say so that observation was necessary to do to provide a reality check.

Moreover, the data of this study were analyzed by using interactive model as proposed by Miles, Hubberman, and Saldana (2014). Firstly, the researchers collected the data through interviews and observation. Secondly, the researches reduced the collected data by selecting it, chose the main data and lost the unimportant data. Then, showed the data in the form of word description. The last was drawing a conclusion. The researchers verified the data and made the initial conclusion to answer the research questions. 


\section{Findings}

\subsection{Students' perception toward using Learn English Conversation application}

In order to find the students' perception toward using Learn English Conversation application in learning speaking, the interview and observation is conducted. Moreover, the interview is based on three components of perception, they are cognitive, conative, and affective component (Walgito, 2010).

\subsubsection{Cognitive component}

This component relates to knowledge, belief, or thought of the participants toward the use of mobile application in learning speaking. Grounded in the data garnered from interview, all five participants have a positive perception towards using Learn English Conversation application in learning to speak in the cognitive domain. In the term of knowledge, the participants have known what the Learn English Conversation application is. For instance, the participant 3 representing other participants said:

"Learn English Conversation application is an application which has many features for facilitating speaking learning". (Participant 3)

From the interview above, participant 3 agreed that the Learn English Conversation application is a mobile application provided by application stores which has various features that can be utilized to facilitate English language learning especially in speaking skills. Basically, the teacher had indeed introduced the application of Learn English Conversation to students as a means to assist them in learning to speak in classroom. The students really welcomed about the use of this application so that they give positive thoughts related the use of Learn English Conversation application. For instance, the participant 1, 3 and 5 said:

\section{"Learn English Conversation application is interesting application". (Participant 1) \\ "Using this application is really fun". (Participant 3) \\ "This application is very good and suitable to help learn speaking". (Participant 5)}

Based on the interview above, participants 1 thought that Learn English Conversation application was an interesting application to be used to facilitate to learn speaking in class. Meanwhile, participant 3 considered that the Learn English Conversation application was an enjoyable speaking learning application. Then, participant 5 thought that Learn English Conversation application was a good application and was suitable for facilitating their speaking learning in the classroom.

Moreover, since all participants had experience in using Learn English Conversation application for speaking learning tool, their' beliefs regarding this application began to emerge. All participants showed positive cognition regarding their beliefs about the use of Learn English Conversation application in the classroom. For instance, participant 2, 3 and 4 said:

"By using the Learn English Conversation, I could learn English pronunciation, intonation, and speech expressions like native speakers." (Participant 2) 
"Honestly, Learn English Conversation application was new to me, and it really helped me in practicing my English speaking. I could learn pronunciation and also get new vocabularies." (Participant 3)

"For me, Learn English Conversation application makes me easy when I was learning English speaking either in class or outside class hours. I could learn how to pronounce English words and the intonation as well." (Participant 4)

Even though Learn English Conversation application was still new for the participants, but it proved that it was beneficial to the participants' language learning, particularly in speaking. All the participants believed that this application could help them in learning several aspects of speaking such as pronunciation, intonation, new vocabularies and even English expressions like native speakers.

\subsubsection{Conative component}

In the conative component, perception refers to actions or activity of the participants. Grounded in the data garnered from the interview, all five participants had a positive perception towards using Learn English Conversation application in the cognitive domain. They expounded some activities they did to enhance their speaking abilities with the help of this application in the classroom. For instance, participant 4 representing participant 1 and 3 said:

"The teacher asked to record our speaking based on the material given on Learn English Conversation application, and we did it. After that, we listened to our pronunciation. When we realized that our pronunciation has not been well, we repeatedly recorded it until we know how to pronounce it well." (Participant 4)

Participant 4 mentioned that recording and repetition were one of learning speaking activities he did by using the Learn English Conversation application which could help them to enhance his speaking abilities. All the students enjoyed recorded their speaking and check whether their pronunciation had been well or not. This was also supported by the results of observations that the students seemed very active when they were doing recording activities. When they got the perfect score, they proudly showed it off to their friends and their teacher. Conversely when they got bad scores they keep repeating their recording activities until they got the perfect score.

Additionally, participant 5 representing participant 2 mentioned other activities he did with the Learn English Conversation application in the classroom and below is the transcript interview.
"My teacher asked to watch some videos in the video lesson feature on Learn English Conversation application. It made us, especially me, easier to understand what my teacher had explained about speaking materials. It was because I could see real examples." (Participant 5)

From the interview above, it could be seen that speaking learning activities using the Learn English Conversation application could not only be done by recording and repetition but also by watching videos provided by the features of this application. By watching those videos from the Learn English Conversation application, they could see real examples of speaking English like a native speaker. Furthermore, they could easily understand the speaking learning material provided by their teacher. This is in line with the results of observation. When their teacher 
explained the speaking material through the videos from Learn English Conversation, the students seemed quickly understood the speaking material provided by their teacher because they saw the real example from the videos.

Besides, this particular component also was focused on revealing the possibility or willingness of the students to use Learn English Conversation application in their speaking learning experience outside the classroom. Several participants shared their experiences about using this application to facilitate them in learning speaking in their free time at home. For instance participant 2, 3 and 5 said:
"After getting bored playing games at home, I opened this Learn English Conversation application to practice my speaking." (Participant 2)
"When I have nothing to do, this application helps me to fill my free time, so I can improve my English speaking skills at the same time." (Participant 3)
"I often use this application to learn speaking with my sister at home." (Participant 5)

From the interview above, participant 2, 3 and 5 who represented other participants, stated that they used the Learn English Conversation application to learn speaking at home. Participants 5 even stated that she practiced speaking using this application together with her sister. However, some of them did not make it as a priority to fill their free time because some participants remarked that they used the Learn English Conversation application to practice their speaking only when they were getting bored playing game.

\subsubsection{Affective component}

In affective component, it refers to feelings or emotional dimension that are not mediated by thinking. Anchored in the data garnered from interview, all five participants affectively had a positive perception towards the use of Learn English Conversation application. For instance, representing other participants, participant 1 and 3 said:

"I was happy and enjoyed using this application because it makes my speaking learning in the classroom more relaxed, and learning time feels fast". (Participant 1)

"Learning English speaking using this application did not make me sleepy. This application brought a new learning atmosphere for me, and I was happy using this application". (Participant 3)

From the interview, the participants claimed that they were happy using Learn English Conversation application because this provided an enjoyable learning nuance that could not be obtained when he learned to speak English only using books. The use of tis application could eliminate their boredom so that the speaking learning process became more fun and made them really feel that the learning time was very short.

Additionally, Learn English Conversation application has several features which can all be used by students to facilitate them in their speaking learning such as audio lessons, speaking lessons, essential phrases, essential words, and chatting with foreigners. All participants mentioned that they had favorite features that they liked to 
use while learning to speak. Participant 1 and participant 5 mentioned their favorite feature in Learn English Conversation application is Audio Lesson. Below is the displayed transcript of interview with participant 1 and 5.

"I like using the Audio Lesson feature because I can learn speaking with my chair mate". (Participant 1)

"My favorite feature on this application is Audio Lesson. I can practice speaking with my friends, and we often compete to get a fivestar score". (Participant 5)

Audio lesson is one of the features in the Learn English Conversation application. Those participants liked using this feature because it contains several conversation texts with a variety of different conversation topics. The participants could practice speaking together with their partner, and when they recorded their conversation, this feature would give them score related to their intonation and pronunciation. Besides, participant 2 and participant 4 stated that they preferred using Essential Word feature. Below is the following transcript of interview with participant 2 and 4.

"If I am asked about my favorite feature in this application, I will answer the Essential Word. I prefer to learn speaking word by word". (Participant 2)

"I love using Essential Word feature. I like practicing speaking from pronouncing words". (Participant 4)

The essential word feature contains numerous words (vocabularies) that students can use to practice word-by-word pronunciation. It could be understood from the above transcript that both participants chose Essential Word feature because they preferred learning or practicing their pronunciation from the basic. Moreover they also could improve their vocabularies. Next, different from the other participant, participant 3 remarked that he adored using all features in Learn English Conversation application. The following transcript of interview with participant 3 is presented below.

"All the features in this application are my favorite features. In my opinion, all the features in this application are exciting for me to use to learn speaking". (Participant 3)

As cited in the above transcript, participant 3 agrees that all features in the Learn English Conversation application were very interesting to use. Those features in this application are very suitable to be used to support students in learning to speak. Furthermore, all features in the Learn English Conversation application were unique to their respective functions.

\subsection{Factor influencing students' perceptions toward using Learn English Conversation Application}

Concerning the data obtained from the interview, there were found four notable factors influencing the students' positive perception towards the use of Learn English Conversion application. The afforested factors are new experience given by Learn English Conversation application; the ease to run this application; flexibility in time and place while using this application; unrequired a lot of internet quota. 


\subsubsection{New experience given by Learn English Conversation application}

The first factor that affects students' positive perception in using Learn English application is the new experience provided by this application. According to participants 1 and 4, one of the factors they were interested in using the Learn English Conversation application was because this application provide a new learning experience for them. Below is the transcript interview with participant 1 and 4:

"I agree that this application brings different experiences when I study in English in the classroom. I recorded my speaking and checked it has been better or not". (Participant 1)

"Since my teacher introducing Learn English Conversation application, it gives me new learning experience in the classroom. I watch several English speaking videos, and I also record my voice to practice speaking". (Participant 4)

From the transcript above, participants 1 and 4 mentioned that the Learn English Conversation application brought a new atmosphere in learning to speak particularly in the classroom. By using the Learn English Conversation application, it provided them multiple new ways to learn speaking. They could see a lot of real examples of English speaking by native speaker in a various situation. Moreover, they could practice speaking English directly through the features offered by the Learn English Conversation application.

\subsubsection{The ease to run the application}

The second factor that affects students' perceptions of the use of the Learn English Conversation application is the ease to run this application. For instance, participant 2 and 3 said:

"Besides having many interesting and useful features, Learn English Conversation application is also effortless to run". (Participant 2)

"The directions on Learn English Conversation application are apparent, so it is easy for me to follow them. Other than that, my teacher has also explained how to use this application before". (Participant 3)

From those transcripts above, participant 2 and 3 agreed that Learn English Conversation application afforded the clear usage instructions. Besides, their teacher had also previously explained how to use Learn English Conversation application so when the students learned to speak using this application, they have no difficulty in operating this application.

An in-line view was also shared by participant 5 as drawn in the following transcript:

"Learn English Conversation application is easy to operate. If I do not understand the English instructions, I can change it to Indonesian". (Participant 5)

Participant 5 revealed the same thought with participant 2 and 3 . She stated the Learn English Conversation application was an application that was easy to run as a medium to facilitate her in learning in learning to speak. Other than that, this 
application did not only provide instructions in English but also several other languages, so if the students did not understand the English instructions, they could use the instructions in their native language such as Indonesian language.

\subsubsection{Flexibility in time and place}

One of the prodigious things Learn English Conversation application offers related to speaking learning is flexibility both in time and place. This is also one of the factors that affects students' perceptions of the use of the Learn English Conversation application. All the participants agreed that they can practice speaking whenever they want, wherever they are. For instance participant 1 and 5 representing other participant said:

"Yes, I can practice my speaking everywhere and every time. I always bring my cellphone. When I was out of school, and I was free, I can practice English speaking". (Participant 1)

"I can learn and practice my speaking without any particular time. I can learn in the morning, afternoon, or evening whether I am in out of the school". (Participant 5)

From the transcript above, those participants remarked that they concurred with flexibility given Learn English Conversation application. They described how they speaking learning became more flexible than before. They could learn to speak English anyplace and anytime. They could practice even when they were away from their regular places of study. It was so because the device is always with them. They always carry their smartphone with them wherever they go such as to the class, to the canteen, before going to bed and so forth.

\subsubsection{Using Low Internet Quota}

Another major factor that makes students willing to use Learn English Conversation application is the use of a little bit internet quota because of the small size of the Learn English Conversation application. For instance, participant 2 said:

"The size of Learn English Conversation application is small so my internet quota is not wasted much. I don't need to worry learning speaking using this application". (Participant 2)

As quoted in the transcript above, participants 2 was not worried to use the Learn English Conversation application as a medium for learning speaking even though sometimes it has to be used online but it did not expend much of their internet quota because of the small size of the application. In line, participant 3 also shared the same opinion by saying:

"This application can be used offline. We only need to download several contents on this application, and it doesn't take up much of my internet quota". (Participant 3)

From the transcript above, participants 3 did not worry on utilizing the Learn English Conversation application in class to facilitate learning speaking. He only needed to download some of the contents of the application then he could use it offline so that it would not use up much of their internet quota. Next is the transcript with participant 4 . 
"Although there is no Wi-Fi available, I have no problem learning using this application because the content that needs to be downloaded does not have large size". (Participant 4)

Just like other participants, participant 4 also had no problem using the Learn English Conversation application in class. Even though, at their school, there was no Wi-Fi connection and they had to download some contents, it would not take up much of their internet quota because the downloaded contents did not have a large size. They were only a few megabytes.

\section{Discussion}

There are two major scopes of findings that are addressed: students' perception toward using mobile application in learning speaking and the factors influencing their perceptions. As revealed from an in-depth interview with five students representing other students, all of them had a positive perception. Their positive perception is constructed by their cognitive, conative and affective evaluations towards using of Learn English Conversation application.

In a term of cognitive component, the students give positive opinion toward using Learn English Conversation application. They agreed that Learn English Conversation application is interesting, good and suitable medium to be used for facilitating their language learning in the classroom. Hence, this application plays an important role to motivate students particularly in learning speaking. It is as Kukulskahulme \& Agnes (2012) says that the use mobile application can motivates the learners to practice the EFL activities. Learn English Conversation application can motivate the students to practice more, as they have the freedom to do speaking activity the time they want in any place they find to be appropriate for them. In addition, the participants believed that the use of Learn English Conversation application brings numerous assistance for them in learning speaking. The technical features in this application have been meant based on skill-practice of language learning intended to provide the students with the ability to acquire necessary speaking skills not only pronunciation but also vocabularies, expressions, and intonation. It is in line as (Uther, 2019) says that the technical features embedded within mobile devices are useful for language learners. Therefore the use of Learn English Conversation application in learning English can assist the students in overcoming their speaking problems such as pronunciation, intonation, expressions and vocabularies.

Moreover, the use of the Learn English Conversation application can also help the students to avoid monotonous speaking learning. This application offers students various ways to learn speaking such as. However, in this study, the participants mention two activities they did in the class room while using this application and one of them is recording and repetition activity. Learning speaking by recording and repetition can be done in almost all the features provided by the Learn English Conversation application. By recording their speaking, the students will know how well they speak. When they feel unsatisfied with their speaking, they will repeat it so that this kind of activity can help the students to improve their speaking skills. This is in line with the statement conveyed by Ahn \& Lee (2016) who have researched mobile application for learning speaking. They argue that doing recording and repetition while learning to speak is an effective way to help improving speaking skill. 
Furthermore, they mention that repetitions after recording on mobile application features encourage students to practice speaking with the same words, expressions, and sentences several times until they became satisfied with their speaking. Then, by doing repetition it will helps the students memorizing words, expressions, and sentences they uttered so their speaking ability automatically will improve.

Moreover, another activity the participant mention while learning speaking using the Learn English Conversation application is watching videos. By watching those videos, it helps students to get a better understanding of the speaking material delivered by their teacher. Furthermore, the students are easier to learn pronunciation, body language, the right intonation like native speakers because by watching the videos students can see the real examples or models and then imitate them. This is in line with the theory from Mirvan (2013) who states that employing video materials in a classroom can help students' to learn because it is able to expose them to a wide variety of situations that can help the students comprehend similar situations in real life.

The students' positive perception toward the use of Learn English Conversation application is also revealed by their willingness to use this application in outside of school hours and most of them use this application to practice speaking at their home. As it is known that to improve students' English speaking ability, it is not enough to only rely on learning speaking at school. The time allocation for learning speaking at school is limited, so students need practice their speaking outside of school hours. With the use of Learn English Conversation application, students can spend their free time to practice their English speaking. The students not only practice by themselves but also they can invite their friends or siblings to practice together so that the learning process will be more fun.

Next, in a term of affective, the students manifested their positive perception in expressing their feeling toward the use of Learn English Conversation application. From the finding, all the participants claimed that they were happy using this application because it can eliminate their boredom while studying in the classroom. Various ways to learn speaking provided by this application bring enjoyable learning to students, and it is in contrast to the traditional way where learning speaking only uses course books. Such this reason is basically in line with (Cavus \& Ibrahim, 2016). They state that using the mobile application, which is on mobile devices for increasing the English learners' proficiency is more effective and more enjoyable compared to using the same materials on paper. Moreover, it is parallel with Saunders (2013) in Cavus \& Ibrahim (2016) who states that presenting only written text would make the learners feel bored and consequently pay much less attention. Then, the same thing also convey by Shamsi, Altaha, \& Gilanlioglu (2019) that the use of m-learning to facilitate learning English can decrease the boredom, which usually arises from the traditional ways of teaching, as well as the time and place limitations.

Students' positive feelings are then supported by a number of application features in the Learn English Conversation application which they mentioned have become their favorite features. Learn English Conversation application has several features which can all be used by students to facilitate them in their speaking learning such as audio lessons, speaking lessons, essential phrases, essential words, and chatting with foreigners. For now on, three features of this application 
such as audio lesson, essential word, and video lesson are the students' favorite feature for speaking learning. The audio lesson feature is chosen because this feature has a number of conversation topics. The participants can practice with their partners by doing role playing using the conversation scripts provided by this feature. Furthermore, students will be even more excited when they record their voices and see how many star scores they have. When they get a perfect score, they will be satisfied with their speaking. Conversely, when they get the lowest score then they will be motivated to repeat the pronunciation until it perfect and they get a perfect score.

Next, the essential words is chosen as a favorite feature is because this application contains various vocabularies so that the participants can improve their vocabularies that they did not know before. Furthermore, they can also practice speaking from the basic by pronouncing word by word. Just like the audio lesson feature, essential word feature can also record participant' speaking. Then, the reason participants choose the video lesson feature as favorite is because this application contains a variety of videos that can be used as learning material for speaking. As stated before by using the video lesson feature, students can not only practice speaking, but also make it easier for them to understand the speaking material provided by their teacher.

In addition, students' positive perceptions toward using Learn English Conversation application were influenced by four factors. The first factor was the new experience given by the Learn English Conversation application. The multiple new ways of learning speaking through this application lead to a new dimension and brings a new atmosphere for students when learning speaking in the classroom. This application supply a lot of real examples of English speaking in a different situation and also offers a lot of features that allow the students to practice their speaking a lot.

Next, the second factor that influenced the students' perceptions was the ease to run the application. Learn English Conversation application provide instructions that are very clear and easy for the students when they use this application. In addition, this application also provides instruction in more than twenty native languages including Indonesian. So, for the students who did not understand the instructions of this application in English, they could change it into their native language such as Indonesian, so they did not feel complicated when running this application in the speaking learning process.

Afterward, the third factor that influenced the students' perceptions was flexibility offered by this Learn English Conversation application. Ahmed (2016) states that mobile applications have been used extensively in learning a second language since smartphones and tablets are available almost all the time. Hence, since the students' smartphone is always with them, it offers students the possibility to learn to speak anytime, anywhere on earth, and at their convenience. The students always carry their smartphones wherever they are such as to their classrooms, canteens, homes, bedrooms, and so on so they can practice speaking even when they are on vacation or away from their regular places of study.

Then, the last factor that influenced the students' positive perceptions was using low internet quota. In fact, the size of the application affects how much internet quota 
should be used. Currently, most students consider internet quota to be very valuable. They prefer to use their internet quota only for entertainment needs such as playing games or playing social media. However, this is different from the Learn English Conversation application. To download this application, it does not require students to use a lot of internet quota because the size of this application is not too large, only 26 megabytes. Other than that, although students must download some material so that later it can be used offline, the size of the materials is also not large enough, it is only a few megabytes so the students do not need to be afraid of running out of their internet quota even though there is no Wi-Fi network available.

\section{Conclusion}

The results of this study show positive perceptions toward the use of the Learn English Conversation application in learning English speaking. From the cognitive aspect, all participants gave positive thoughts and believed that the use of Learn English Conversation application brings many advantages to support the students' English speaking learning both inside and outside the classroom. According to participants' opinion, Learn English Conversation application provide excellent learning opportunities, particularly in overcoming students' speaking problems such as pronunciation, intonation, and vocabularies and expressions. Concerning the conative aspect, the participants mentioned about their positive activities during the use of Learn English Conversation application in learning to speak, help them to improve their speaking ability so they also willing to use this application at outside of school hours to spend their free time. Moreover, the participants also shared their positive feeling toward the use of Learn English Conversation application in English speaking learning. All the students are happy using this application because this application brings them more enjoyable learning rather than using course books. Some underlying factors which influenced their positive perceptions were also found and extended to giving them new experiences in speaking learning, one of the learning tools that easy to use, unrequired a lot of internet quota, and the most important one is the flexibility learning in time and place.

\section{References}

Ahmed, H. B. E. (2016). Duolingo as a Bilingual Learning App: a Case Study. Arab World English Journal (AWEJ), 7(2), 255-267.

Ahn, T., \& Lee, S. (2016). User experience of a mobile speaking application with automatic speech recognition for EFL learning. British Journal of Educational Technology, 47(4), 778-786. https://doi.org/10.1111/bjet.12354

Al-sobhi, B. M. S., \& Preece, A. S. (2018). Teaching English Speaking Skills to the Arab Students in the Saudi School in Kuala Lumpur: Problems and Solutions. International Journal of Education \& Literacy Studies, 6(1), 1-11. http://dx.doi.org/10.7575/aiac.ijels.v.6n.1p.1

Cavus, N., \& Ibrahim, D. (2016). Learning English using children's stories in mobile devices. British Journal of Educational Technology, (2011), 1-17. https://doi.org/10.1111/bjet.12427

Comas-Quinn, A., Mardominggo, Raquel, \& Valentine, C. (2009). Mobile Blogs in Language Learning: Making the Most of Informal and Situated Learning Opportunities. $\quad$ ReCALL, 21(1), 96-112. 
http://dx.doi.org/doi:10.1017/S0958344009000032

Coskun, A. (2016). Causes of the "I Can Understand English but I Can"t Speak' Syndrome in Turkey. I-Manager's Journal on English Language Teaching, 6(3), $1-12$.

Ekinci, E., \& Ekinci, M. (2017). Perceptions of EFL Learners about Using Mobile Applications for English Language Learning: A Case Study. International Journal of Language Academy, 5, 175-193. http://dx.doi.org/10.18033/ijla.3659

Godwin-jones, R. (2011). Emerging Technologies Mobile Apps for Language Learning. Language Learning \& Technology, 15(2), 2-11.

González, J. F. (2012). Can Apple's iPhone Help to Improve English Pronunciation Autonomously? State of the App. CALL: Using, Learning, Knowing. EUROCALL Confrence, 81-87. Gothenburg, Sweden: Dublin 2012.

Guo, H. (2015). Analysing and Evaluating Current Mobile Applications for Learning English Speaking Author Name: Hui Guo. Birkbeck, University of London.

Hamad, M. M., Metwally, A. A., \& Alfaruque, S. Y. (2019). The Impact of Using YouTubes and Audio Tracks Imitation YATI on Improving Speaking Skills of EFL Learners. English Language Teaching, 12(6), 191-198. https://doi.org/10.5539/elt.v12n6p191

Han, T., \& Keskin, F. (2016). Using a Mobile Application (WhatsApp) to Reduce EFL Speaking Anxiety. Gist Education and Learning Research Journal, 12, 29-50.

Howlett, G., \& Waemusa, Z. (2019). 21st Century Learning Skills and Autonomy: Students' Perceptions of Mobile Devices in the Thai EFL Context. Teaching English with Technology, 19(1), 72-85.

Kukulska-hulme, \& Agnes. (2012). Language Learning Defined by Time and Place: A Framework for next Generation Designs. Left to My Own Devices: Learner Autonomy and Mobile Assisted Language Learning. Innovation and Leadership in English Language Teaching, 6, 1-13. http://dx.doi.org/doi:10.1108/S2041272X(2012)0000006004

Kukulska-hulme, Agnes, \& Shield, L. (2008). An overview of mobile assisted language learning: From content delivery to supported collaboration and interaction. ReCALL, 20(3), 271-289. http://dx.doi.org/doi:10.1017/S0958344008000335

Liu, Q., \& He, X. (2014). Using Mobile Apps to Facilitate English Learning For Collage Students in China. University of Boras.

Machmud, K., \& Abdulah, R. (2018). Using Mobile Phone to Overcome Students ' Anxiety in Speaking English. SHS Web of Confrences, 42, 1-6. https://doi.org/10.1051/shsconf/20184200004

Mehta, N. K. (2012). Mobile Phone Technology in English Teaching: Causes \& Concerns. The Modern Journal of Applied Linguistics, 2(4), 82-92.

Miles, M., Huberman, M., \& Saldana, J. (2014). Qualitative Data Analysis, a Methods Sourcebook, Edition 3. USA: Sage Publication

Mirvan, X. (2013). The Advantages of Using Films to Enhance Student's Reading 
Skills in the EFL Classroom. Journal of Education and Practice, 4(13), 62-67.

Robson, C. (2002). Real World Research. Oxford: John Wiley and Sons Ltd.

Shamsi, A. F., Altaha, S., \& Gilanlioglu, I. (2019). International Journal of Linguistics, Literature and Translation ( IJLLT ) ISSN : 2617-0299 The Role of M-Learning in Decreasing Speaking Anxiety for EFL Learners. International Journal of Linguistics, Literature and Translation (IJLLT), 2(1), 276-282. https://doi.org/10.32996/ijltt.2019.2.1.34

Uther, M. (2019). Education sciences Mobile Learning - Trends and Practices. Education Sciences, 10-12. https://doi.org/10.3390/educsci9010033

Walgito, B. (2010).Pengantar Psikologi Umum.Yogyakarta:Andi 